\title{
Inferior rectus nasal transposition as a procedure of choice for acquired superior oblique palsy
}

This article was published in the following Dove Press journal:

Clinical Ophthalmology

9 November 2015

Number of times this article has been viewed

Hrishikesh Kaza'

Vivekanand U Warkad ${ }^{1,2}$

'Pediatric Ophthalmology, Strabismus and Neuro-Ophthalmology, L V Prasad Eye Institute, ${ }^{2}$ Miriam Hyman Children's Eye Care Centre, Pediatric Ophthalmology, Strabismus and Neuro-Ophthalmology, LV Prasad Eye Institute, Bhubaneswar, India
Correspondence: Vivekanand U Warkad Miriam Hyman Children's Eye Care Centre, Pediatric Ophthalmology, Strabismus and Neuro-Ophthalmology, L V Prasad Eye Institute, Infocity Road, 347, Chandaka Industrial Estate, Patia, Bhubaneswar, Odisha - 751024, India Tel +9l 6743987206

Fax +91 6743987130

Email vivekwarkad@yahoo.com

\section{Dear editor}

It is with great interest that we read the paper published by Okamoto et al. ${ }^{1}$ In this paper, the authors retrospectively evaluated 135 cases who underwent inferior rectus nasal transposition for acquired or decompensated superior oblique palsy. The authors concluded that inferior rectus nasal transposition decreased the excyclotorsion effect with the added advantage of long-term stability and also allowing for simultaneous correction of the vertical deviation.

They have positively described the effect of inferior rectus nasal transposition, as the surgery does not involve any procedure on the oblique muscles in the first place. Also, as described by the authors, retaining the superior conjunctiva for glaucoma filtration surgeries, if need be, makes it a novel approach. Lesser postoperative incidence of Brown's syndrome is an added advantage.

In support of preferring inferior rectus nasal transposition to the Harada-Ito procedure, the authors state that the latter was associated with a higher rate of regression. But the study quoted in this regard, ie, that by Nishimura and Rosenbaum, ${ }^{2}$ shows that few patients had a follow-up period of more than 1 year, which may be inadequate to draw a conclusion. Moreover, in a subsequent study ${ }^{3}$ with a minimum follow-up period of 2 years, it was found that regression was encountered in fewer cases than reported previously.

We also feel the paper is lacking in a few important details which would influence the outcome of the surgery. Superior oblique palsy is known to have a vertical deviation in the form of hypertropia in most cases. ${ }^{4}$ Okamoto et al, though not mentioned clearly, from what we could interpret, performed inferior rectus recession on the ipsilateral side along with an inferior rectus nasal transposition in most cases, and this cannot explain the correction of hypertropia. Inferior rectus recession is likely to induce further hypertropia in the involved eye. Inferior rectus recession, if at all, has been performed in the other eye in order to achieve symmetry, as done by Kushner. ${ }^{5}$ Also, the amount of hypertropia to be corrected preoperatively and the postoperative residual amount are important considerations which were not mentioned in the study.

Okamoto et al considered a minimum follow-up period of 3 months, which we feel is insufficient to conclude that this procedure offers long-term stability. As there were a total of eight cases where regression was encountered, five occurring within 1 year of surgery and three cases occurring after 1 year, longer follow-ups may have led to a different outcome.

To conclude, inferior rectus nasal transposition may be considered as a good alternative to the Harada-Ito procedure, and may additionally be done as a procedure of 
choice in cases with minimal vertical deviation and minimal inferior oblique overaction as in cases of Knapp class II superior oblique paresis or when a previous oblique muscle surgery has been performed. ${ }^{6}$

\section{Disclosure}

The authors report no conflicts of interest in this communication.

\section{References}

1. Okamoto M, Kimura A, Masuda A, Mimura O. Surgical effects of nasal transposition of inferior rectus muscle -135 cases of acquired superior oblique palsy. Clin Ophthalmol. 2015;9:691-695.
2. Nishimura JK, Rosenbaum AL. The long-term torsion effect of the adjustable Harada-Ito procedure. J AAPOS. 2002;6(3):141-144.

3. Bradfield YS, Struck MC, Kushner BJ, Neely DE, Plager DA, Gangnon RE. Outcomes of Harada-Ito surgery for acquired torsional diplopia. $J$ AAPOS. 2012;16(5):453-457.

4. Bagheri A, Fallahi MR, Abrishami M, Salour H, Aletaha M. Clinical features and outcomes of treatment for fourth nerve palsy. J Ophthalmic Vis Res. 2010;5(1):27-31.

5. Kushner BJ. Vertical rectus surgery for Knapp class II superior oblique muscle paresis. Arch Ophthalmol. 2010;128(5):585-588.

6. von Noorden GK, Jenkins RH, Chu MW. Horizontal transposition of the vertical rectus muscles for cyclotropia. Am J Ophthalmol. 1996; 122(3):325-330. 


\section{Authors' reply}

Mana Okamoto

Akiko Kimura

Akiko Masuda

Osamu Mimura

Department of Ophthalmology, Hyogo College of Medicine Hospital, Nishinomiya, Japan

Correspondence: Mana Okamoto

Department of Ophthalmology, Hyogo College of Medicine Hospital,

I-I Mukogawa-cho, Nishinomiya City, Hyogo, 663-850 I, Japan

Tel +81798456462

Fax +8I 798456464

Email manamana429@gmail.com

\section{Dear editor}

We are afraid Kaza and Warkad have had a big misunderstanding. Our paper indicated that inferior rectus (IR) recession was performed not on the affected eye, but on the fellow eye (hypotropic eye). We performed IR recession and nasal transposition on the hypotropic eye (non-affected eye) for acquired superior oblique (SO) palsy. In the case of congenital SO palsy, inferior oblique (IO) overaction is severe and SO under-action is also observed; therefore, the surgical treatment as the first choice is mostly Harada-Ito procedure or IO recession on the affected eye. However, in the case of acquired SO palsy, IO overaction is not markedly observed and the patients with acquired SO palsy complain of cyclodiplopia dominantly. ${ }^{1,2}$ Therefore, IR nasal transposition is more effective to correct cyclodeviation compared to SO procedure on affected muscle or IO recession on the affected eye.

For vertical deviation, the surgical effect of IR recession and nasal transposition reduced from $5.3^{\circ} \pm 0.3^{\circ}$ preoperatively to $1.0^{\circ} \pm 0.2^{\circ}$ postoperatively in 75 cases out of 90 cases with one muscle width of IR nasal transposition. The surgical effect was $2.1^{\circ} \pm 0.2^{\circ} / \mathrm{mm}$. Meanwhile, the surgical effect of IR resection and nasal transposition reduced from $4.0^{\circ} \pm 1.3^{\circ}$ preoperatively to $4.0^{\circ} \pm 1.2^{\circ}$ postoperatively in four cases. The surgical effect was $0.6^{\circ} \pm 0.6^{\circ} / \mathrm{mm}$. The effect of IR recession to correct vertical deviation was stable compared to that of IR resection after 3 months. This is because we selected the IR recession and nasal transposition as the firstchoice procedure. We are sure that the IR recession and nasal transposition on the non-affected eye was more effective and suitable to correct cyclotorsion and vertical deviation than IR resection and nasal transposition on the affected eye. However, in our paper, we focused on just the correction of cyclotorsion induced by IR nasal transposition.

We had ten long-term follow-up cases whose median follow-up period was 6 years (3-10 years). One case (10\%) had reoperation 6 years after the first surgery because of recurrence of vertical diplopia, not cyclodeviation. Cyclotorsion was stable after the first surgery. Meanwhile, nine cases $(90 \%)$ had no double vision in the primary position and their vertical deviation and cyclotorsion were stable after the first surgery. In all ten cases, cyclodeviation had few exacerbations; therefore, IR nasal transposition offers long-lasting stability in cyclotorsion.

We are preparing long-term follow-up data in patients with acquired SO palsy treated with IR nasal transposition because we also think that long-term follow-up is necessary to evaluate this procedure.

\section{Disclosure}

The authors report no conflicts of interest in this communication.

\section{References}

1. Helveston EM, editor. Telemedicine: distance medicine. In: Surgical Management of Strabismus. 5th ed. Belgium: Wayenborgh Publishing; 2005:151-153.

2. Plager DA, editor. Oblique muscle dysfunction. In: Strabismus Surgery: Basic and Advanced Strategies. Oxford and New York, NY: Oxford University press; 2004:55-60.

Dove Medical Press encourages responsible, free and frank academic debate. The content of the Clinical Ophthalmology 'letters to the editor' section does not necessarily represent the views of Dove Medical Press, its officers, agents, employees, related entities or the Clinical Ophthalmology editors. While all reasonable steps have been taken to confirm the content of each letter, Dove Medical Press accepts no liability in respect of the content of any letter, nor is it responsible for the content and accuracy of any letter to the editor.

Clinical Ophthalmology

\section{Publish your work in this journal}

Clinical Ophthalmology is an international, peer-reviewed journal covering all subspecialties within ophthalmology. Key topics include: Optometry; Visual science; Pharmacology and drug therapy in eye diseases; Basic Sciences; Primary and Secondary eye care; Patient Safety and Quality of Care Improvements. This journal is indexed on

\section{Dovepress}

PubMed Central and CAS, and is the official journal of The Society of Clinical Ophthalmology (SCO). The manuscript management system is completely online and includes a very quick and fair peer-review system, which is all easy to use. Visit http://www.dovepress.com/ testimonials.php to read real quotes from published authors. 